Sex, Alcohol, and Soul : Violent Reactions to Coming Out after pÿthe Gay Propaganda Law in Russia

Kondakov, Alexander

2021-01

Kondakov , A \& Shtorn , E 2021 , ' Sex, Alcohol, and Soul : Violent Reactions to Coming Out

pÿafter the Gay Propaganda Law in Russia ' , Russian Review , vol. 80 , no. 1, pp. 37-55 . https://doi.org/10.1111/r

http://hdl.handle.net/10138/338525

https://doi.org/10.1111/russ.12297

unspecified

acceptedVersion

Downloaded from Helda, University of Helsinki institutional repository.

This is an electronic reprint of the original article.

This reprint may differ from the original in pagination and typographic detail.

Please cite the original version. 
This work appeared in:

Kondakov, A.S. and SHTORN, E. (2021), Sex, Alcohol, and Soul: Violent Reactions to Coming

Out after the "Gay Propaganda" Law in Russia. The Russian Review, 80 (1): 37-55.

https://doi.org/10.1111/russ.12297

\title{
Sex, Alcohol, and Soul: Violent Reactions to Coming Out after the "Gay Propaganda" Law in Russia
}

\author{
Alexander Sasha Kondakov and Evgeny Shtorn
}

Several years ago, a group of three men decided to celebrate International Women's Day on March 8. Their plan was set in motion as they met at a mutual friend's apartment. Two of the men had alcohol with them. They wanted the third man to join their company. Eventually, the three men relocated to another private apartment and started drinking. As one participant recalls,

\begin{abstract}
they sat at the table, began to drink alcohol. [Name4] had just one drink and then went to another room to take a nap. But [the defendant] and [the victim] continued to sit at the table together, drinking and chatting. They entered into a conversation about women. [The victim] requested that [the defendant] congratulate him on the holiday they were celebrating. [The defendant] was surprised and pointed out that this was a women's holiday. Then, [the defendant] realized that [the victim] was revealing his non-traditional sexual orientation to him. [The defendant] began persuading [the victim] that [the victim] was not right to say this. They argued, but [the victim] would not agree.
\end{abstract}

Eventually, the defendant stabbed the victim in the neck with the kitchen knife that they had used to prepare appetizers. This story exemplifies a very common script of violent

${ }^{1}$ See case \#1-221/2015, heard in Dmitrov, Moscow Region, available at https://bsr.sudrf.ru/bigs/portal.html. All quotations originally in Russian have been translated by the authors.

The authors would like to thank Roman Utkin, Darryl Hill, and Alexandra Novitskaya for their helpful comments on an earlier draft of this paper. We are grateful to the Rosa Luxemburg Foundation - Moscow for supporting the initial idea of the Database on Violence against LGBT People in Russia. Part of the argument was defended by one of the authos as an M.A. dissertation at the National Research University - Higher School of Economics in St. Petersburg.

[37]

incidents against queer people in Russia, as documented in the federal criminal court records database. These crimes typically involve a private group of men, excessive consumption of hard liquor, some kind of manifestation of homosexuality that upsets the drinking mates, and the ensuing scuffle which leads to murder or serious injury involving a kitchen knife or other immediately available cutlery. Therefore, these are also stories about common interactions between men during which social norms and expectations are disrupted. Violence turns out to be a highly likely outcome of these disruptions. Masculinity and alcohol appear to be central to the stories.

In this article, we limit our study of violence against queer people in Russia to one particular set of interactions: situations involving the consumption of alcohol by men and the culture of collective drinking that supports a set of social norms. For example, in the excerpt above, some specific rules of masculine collective drinking are followed: the number of men engaged in drinking is important, and three people is regarded as acceptable because two could be perceived as a romantic date, while drinking alone could be interpreted as a sign of alcoholism. We review some of these norms further to find out whether breaking these rules by a queer coming out triggers violence, and if so, why? We analyze how queer sexuality fits, or rather does not fit, into the picture of collective drinking. Using court files, we look into the social rules of alcohol consumption to understand why people whose homosexuality is revealed during these gatherings end up dead or severely injured. In other words, this study is not of overall violence against queer people in Russia, but a review of a smaller sample of cases that deal more specifically with assertions of masculinity during drinking rituals. 
Although our information is limited to the cases heard at criminal courts, we nevertheless argue that by looking at extreme situations, we can better understand the broader picture of violence against queer Russians in the wake of the so-called "gay propaganda" law. This bill was adopted by the State Duma in the summer of 2013 and meant to "protect children from information that promotes denial of traditional family values." ${ }^{2}$ It amended several federal laws and the Code of Administrative Offences of the Russian Federation with the final purpose of banning public access to something called "propaganda of non-traditional sexual relations." Hence, the "propaganda" law is censorship legislation that limits people's freedom of expression and access to information. However, it has had effects beyond its official purpose.

Just like probably any censorship law, and contrary to its objective, the bill generated a lot of interest in LGBTQ issues and sparked increased media output on the topic. ${ }^{3}$ Much of this interest disseminated hatred so as to convince the public in dangers of homosexuality. Nonetheless, other publications conveyed a more positive image of LGBTQ people. This in turn generated enforcement of the law across Russia. For the years 2013-18 there were

${ }^{2}$ Alexander Kondakov, "The Censorship "Propaganda” Legislation in Russia," in: State-Sponsored Homophobia, 13th ed., L. R. Mendos (Geneva, 2019), 213-15.

${ }^{3}$ Emil Edenborg, Politics of Visibility and Belonging: From Russia's "Homosexual Propaganda" Laws to the Ukraine War (London, 2017); Elena Pronkina, "Osobennosti LGBT-diskursa v rossiiskikh media, initsirovannogo diskussiiami o regulirovanii seksual'nosti," Zhurnal issledovanii sotsial'noi politiki 1 (2016): 71-86.

fifty-seven court decisions in the official state registrar citing this legislation. ${ }^{4}$ More to the point of this study of violence, the law also has had social effects beyond its implementation. Violence against queer people in Russia grew substantially after 2013, and the number of victims of such violence doubled by $2015 .{ }^{5}$ One of the possible explanations of this growth is that the "gay propaganda" law (as an official enunciation) communicated the idea of impunity to potential perpetrators of homophobic violence. This resulted in more people deciding to act aggressively in their everyday encounters with sexual diversity, and some of those encounters ended in murder.

Whereas this overall picture seems convincing and is supported by quantitative calculations, it is worth looking at the violent episodes from a more qualitative perspective. This article does exactly this by getting deeper into the analysis of some crime scenes of homophobic violence that involved the consumption of alcoholic beverages. We understand that not all drunken conversations about homosexuality lead to a knife fight. In fact, many people may react with acceptance, indifference, or even passionate sexual feelings to a queer coming out in a company of drinking pals. Here, however, we focus only on those episodes that involved violence and were prosecuted within the criminal justice system. We believe that the cases that feature coming out and a violent reaction to it reflect a relationship at the intersection between masculinity and queer sexuality, which is the subject of this study. By examining violence at men's drinking gatherings, we hope to expand our knowledge about masculinity, sexuality, and the culture of drinking in Russia. ${ }^{6}$

Having this goal in mind, we further review literature on the ethnography of drinking. It mostly focuses on Russia and the interconnections between the consumption of alcohol and violence. Thus, ethnographic accounts are intertwined here with criminological studies. We then shift our attention to the methodology of reading the court documents on which this research is based. We detail the various languages contained in the documents to show how studying crime scenes can be done even with limited sources. Our final section evolves around an analysis of the violent encounters between queer victims and the perpetrators of homophobic violence that start with heavy vodka-drinking.

\section{THE RITUAL OF DRINKING}

Drinking alcohol collectively is a long-established tradition in Russia. ${ }^{7}$ Historians have argued that the consumption of vodka can be viewed as a ritual because it involves many

${ }^{4}$ Kondakov, “The Censorship 'Propaganda' Legislation in Russia,” 215. 

${ }^{5}$ Alexander Kondakov, “The Influence of the 'Gay-Propaganda' Law on Violence against LGBTIQ People in Russia: Evidence from Criminal
Court Rulings," European Journal of Criminology (2019): 13.

${ }^{6}$ The links between homosexuality and men's drinking gatherings have not been studied in detail so far. Laurie Essig starts a conversation about alcohol and homosexuality in her discussion of Eduard Limonov's autobiographical fiction. See Essig, Queer in Russia: A Story of Sex, Self, and the Other (Durham, NC, 1999), 148. Dan Healey discusses in more detail men's drinking gatherings as homosocial relationships and "rituals of friendship, status construction, and courtship between men," in his Russian Homophobia from Stalin to Sochi (London, 2018 ), 63.

${ }^{7}$ Patricia Herlihy, “Joy of the Rus': Rites and Rituals of Russian Drinking,” Russian Review 50 (April 1991): 131-47; Grigorii Grigor'evich Zaigraev, "Osobennosti rossiiskoi modeli potrebleniia nekommercheskogo alkogolia," Sotsiologicheskie issledovaniia 12:2 (2002): 39.

people, and often marks important events in people's lives (family events such as weddings and funerals, or common celebrations marking the harvest, or religious and state festivals): "The rituals, customs, and traditional culture of drinking in Russia assumed that one drank in company," noted Patricia Herlihy. "As a temperance advocate remarked in 1894, the simple man of the people (prostoliudin) thought "vodka was not vodka, if he did not drink it in the company of others." " This idea still remains important in current norms of drinking alcohol,aspeopletendtogatheringroupsofatleastthreebeforeopeningabottle. ${ }^{9}$ However, many norms have changed over time, especially during the twentieth century with its specific conditions of Soviet modernity. In this study, we focus on violent episodes during contemporary drinking gatherings that ended up in the criminal justice system in our search for violence against queers in Russia.

Criminological and sociological literature has highlighted significant correlations between the consumption of alcohol and violence in various countries, including Russia. ${ }^{10}$ The existing research suggests that drinking hard liquor increases the chances of fatal accidents and overall mortality rates: "a [one] liter increase in vodka sales would result in a 9.8 percent increase in the male accident mortality rate and [a] 7.5 percent increase in female mortality rates," Yury Razvodovsky has observed. "The association between beer sales per capita and fatal accident rates was also positive for both sexes, but not significantly." ${ }^{11}$ Furthermore, criminologists contend that the majority of violent offenders are under the influence of alcohol when committing their crimes: in Russia, the percentage of intoxicated felons by the end of the 1990s was 70 percent and the consumption of alcohol continues to be highly correlated with perpetrators' violent behavior. ${ }^{12}$ William Pridemore has found that homicide rates increase by 0.25 percent with every 1 percent increase in the consumption of alcohol across various regions of Russia. ${ }^{13}$ Moreover, a closer look at criminal case files reveals that not only offenders, but also almost half of the victims, were drinking alcohol during the incidents. ${ }^{14}$ This finding opens up further questions about violent interactions involving alcohol.

Importantly, violence under the influence of alcohol is extremely gendered: the availability of alcohol significantly increases the probability of death from intimate partner violence among women in the United States, for example. ${ }^{15}$ The same is true for Soviet and

${ }^{8}$ Herlihy, "Joy of the Rus'," 146.

${ }^{9}$ David Koester, "Drink, Drank, Drunk: A Social-Political Grammar of Russian Drinking Practices in a Colonial Context," Anthropology of East Europe Review 21:2 (2003): 45.

${ }^{10}$ Jonas Landberg and Thor Norström, "Alcohol and Homicide in Russia and the United States: A Comparative Analysis," Journal of Studies on Alcohol and Drugs (September 2011): 723-30.

${ }^{11}$ Yury Razvodovsky, “The Effect of Beverage Type on Fatal Accidents Rate in Russia,” Alcoholism and Psychiatry Research 51 (2015): 36. See also Andrew Stickley and Yury Razvodovsky, "The Effects of Beverage Type on Homicide Rates in Russia, 1970-2005," Drug and Alcohol Review 31 (2012): 257-62.

${ }^{12}$ Valeriy V. Chervyakov et al., "The Changing Nature of Murder in Russia," Social Science \& Medicine 55 (2002): 1720-21; William Alex Pridemore, "An Exploratory Analysis of Homicide Victims, Offenders, and Events in Russia," International Criminal Justice Review 16:1 (2006): 5-23. 
${ }^{13}$ William Alex Pridemore, “Vodka and Violence: Alcohol Consumption and Homicide Rates in Russia," Public Health Matters 92:12 (2002): $1921-30$.

${ }^{14}$ Pridemore, "Exploratory Analysis of Homicide Victims," 8.

${ }^{15}$ Darryl W. Roberts, "Intimate Partner Homicide: Relationships to Alcohol and Firearms," Journal of Contemporary Criminal Justice 25:1 (2009): 67-88.

post-Soviet societies. ${ }^{16}$ Situations where victims of violence are targeted based on male perpetrators' perception of their gender expression as feminine have become known as feminicide, to highlight the power relations that trigger this violence. ${ }^{17}$ In contrast to "femicide" used in criminology as a case of "homicide," feminicide "means a murder of a feminine being or a human with characteristics of women, no matter if she is a woman or not."18 Thisdistinctionmakesthetermmoreinclusive, whilestillsuggestingthatagendered power dynamic is a characteristic of these crimes. It does not mean that male victims are per se feminine due to their homosexual orientation; what it means is that perpetrators interpret homosexuality of male victims as a sign of femininity. Thus, male victims of feminicide are punished for expressions that the perpetrators consider not masculine. Certainly, cases like these would include many transgender victims. ${ }^{19}$ However, in our sample of felonies that involve alcohol and coming out, the victims were male-identified, and their masculinity was perceived by the perpetrators to be corrupted by an expression of homosexuality.

Taking these criminological findings into account, we look into the culture and ritual of drinking alcohol in Russia in order to understand what sort of social mechanism facilitates the eruption of violence fueled by alcohol during collective gatherings. ${ }^{20}$ Criminologists and some sociologists usually maintain that alcohol blurs the perpetrators' perception of the situation, obscures their rational judgment, and eventually results in violent offenses which they later regret when sober. These explanations rely heavily on the psychological and physical effects of alcoholic intoxication. However, very often cultural anthropological understandings of social interactions shed new light on the events in question. ${ }^{21}$ What if certain patterns of the social ritual were disturbed, or particular social expectations were not met at the time of an alcoholic festivity? Could such a socially relevant but most commonly unacknowledged event lead to an outbreak of violence? Would the understanding of these social norms and their functioning in society enrich criminological explanations of the correlation between alcohol and violence? In other words, we do not propose to jettison the argument that alcohol influences people's psyches and distorts their perception of an event via a set of chemical reactions. Rather, we wish to add to it an examination of the cultural context of drinking and acting violently. After all, as sociologists in Russia suggest,

the consumption of alcohol has certain psychological functions (it facilitates relaxation, detracts attention from problems, reduces anxiety, raises good mood, and gives pleasure). But it also has important social functions. Consumption

\footnotetext{
${ }^{16}$ Marianna G. Muravyeva, “Bytovukha: Family Violence in Soviet Russia,” Aspasia 8 (2014): 97.

${ }^{17}$ Rosa-Linda Fregoso and Cynthia Bejarano, "Introduction: A Cartography of Feminicide in the Américas," in Terrorizing Women: Feminicide in the Américas, ed. R.-L. Fregoso and C. Bejarano (Durham, 2010), 1-42.

${ }^{18}$ Julia Estela Monárrez Fragoso, Trama de una injusticia: Feminicidio sexual sistémico en Ciudad Juárez (Tijuana, 2009), 35.

${ }^{19}$ For more details on violence against trans* people in an earlier report see Alexander Kondakov's Prestupleniia na pochve nenavisti protiv LGBT v Rossii (St. Petersburg, 2017), 80.
}

\footnotetext{
${ }^{20}$ We follow Mikhail Sokolov's proposal to regard the consumption of alcohol as an interaction ritual. See Sokolov, "P'ianka: Issledovanie sotsial'nogo proizvodstva opyta ne-identichnosti," in Bespredel'naia sotsiologiia: Perezagruzka, ed. N. Nartova et al. (St. Petersburg, 2006), $47-60$.

${ }^{21}$ Mary Douglas, “A Distinctive Anthropological Perspective," in Constructive Drinking: Perspectives of Drink from Anthropology, ed. Mary Douglas (London, 2003), 3-15.
} 
of alcohol is an action performed together with acquaintances, relatives, colleagues, team members, and friends that facilitates socialization (conversation, communication, social, and personal networking, display of trust, hospitality and friendship) and it is inherent to celebrations of important events in people's life. ${ }^{22}$

Anthropologist Stephan Dudeck offers an understanding of the practice of alcohol consumption as a "social catalyst" because it "enables certain things to happen that would not happen or would not happen so quickly and easily without it". ${ }^{23}$ As a "social lubricant," alcohol facilitates intimate communication in many different respects: from sharing personal information and concerns to sexual engagement. At its core, the consumption of alcohol is a communicative practice with specific norms of engagement: people may cross boundaries that they usually do not cross, and they may do it in the social space that collective alcohol drinking creates. Notably, anthropologists usually talk about collective practices of alcohol consumption, because it is within this immediate group of drinkers where social norms are constructed and reproduced: drinking is, therefore, a mechanism for creating social unity. ${ }^{24} \mathrm{We}$ offer a way of looking at this unity as a sort of interaction ritual. ${ }^{25}$

When speaking about unity, however, we specifically refer to an exclusive group who base their social bonds in their gender. To be precise, in this study we are looking at the construction of male heterosexual bonding: what disrupts it, and what makes it stronger. In other words, we scrutinize how heterosexual masculinity can so easily be disturbed by the queer men who become victims of violence once their sexuality is revealed and they are perceived as feminine by the perpetrators because of it. Masculinity has a performative character as a set of repetitive actions compliant with societal expectations, and although many different versions of masculinity circulate in a society, one of them dominates as "hegemonic." 26 When feeling insecure in one aspect of their hegemonic masculinity (being a "provider for the family," for example), some men invest more effort in its other aspects (such as violent behavior). ${ }^{27}$ As this violent behavior is most often directed at women and gay men, it is evident that gender and sexuality play a crucial role in the construction of masculinity when insecure men try to prove they are "man" enough and distance themselves from women and queers by being violent. ${ }^{28}$ The fragility of heterosexual masculinity is exactly this situation: the feeling of threat to a man's masculinity triggered by being in the presence of a gay man. We look at how this fragile heterosexual masculinity plays out during drinking rituals in Russia.

${ }^{22}$ Vera Sergeevna Tapilina, "Skol'ko p'et Rossiia? Ob"em, dinamika i differentsiatsiia potrebleniia alkogolia," Sotsiologicheskie issledovaniia 2 (2006): 85

${ }^{23}$ Stephan Dudeck, “'Do You Respect Me?' Drinking as a Social Catalyst in the Reindeer Herding Communities of European Russia and Western Siberia," Folklore 61 (2015): 93.

${ }^{24}$ Eeva Kesküla, "Fiddling, Drinking and Stealing: Moral Code in the Soviet Estonian Mining Industry," European Review of History 20:2 (2013): 246.

${ }^{25}$ This approach is inspired by many classical anthropological studies of drinking behavior. See Sokolov, "P'ianka"; and Douglas, "A Distinctive Anthropological Perspective".

${ }^{26}$ Judith Butler, Bodies That Matter: On the Discursive Limits of Sex (New York, 1993); Raewyn Connell, Masculinities (Berkeley, 1995).

${ }^{27}$ Michael Kimmel, The Gender of Desire: Essays on Male Sexuality (Albany, 2005), 195.

${ }^{28}$ C. J. Pascoe, Dude, You're a Fag: Masculinity and Sexuality in High School, 2nd ed. (Berkeley, 2011).

One of the major ideas that we want to highlight, then, is that the ritual of consumption of alcohol in contemporary Russia has a great deal to do with masculinity and, therefore, that drinking rituals are mostly directed at supporting 
the reproduction, confirmation, and assertion of masculinity. ${ }^{29}$ Drinking strong alcohol is usually viewed as a practice between men. ${ }^{30}$ In Russia, "drinking was predominantly a masculine activity, and this setting transformed into one of the pivotal sites of interaction where masculinities were continually constructed, negotiated, and enacted." ${ }^{31}$ In this sense, drinking alcohol is a way to establish who is man enough by showing others how much one can drink without losing control. The ability to drink is associated with gender:

Within a hierarchy of masculinities, dominant and submissive gender forms emerge from immediate contexts of interaction over time. Specifically, the language of Russian workingmen reflects the deep and pervasive link between drinking and gender. Drinking and drunkenness were masculine behaviors; sobriety and abstention, especially from strong spirits, were appropriately feminine traits. ... [T] his connection is perhaps most notable in workingmen's remarks toward their peers, where men often used a number of feminized and emasculating epithets to call into question the maturity, sexual identity, and masculinity of nondrinking men. ${ }^{32}$

Thus, the ritual of drinking alcohol establishes a hierarchy of masculine identities: it is precisely this hierarchy that the social interaction produces and sustains. We propose to think about these identities as a spectrum of various masculinities that are questioned during the drinking ritual and then positioned relationally to one another if confirmed and recognized. There are several major ceremonial rules of this interaction ritual. First of all, the interaction occurs between men, so those allowed to participate should confirm their masculinity to engage in the process, while there is an outside group of "non-men" who are excluded. ${ }^{33}$ The excluded may be asked to leave the common table: it would be "offensive" for these other men to drink with them, especially in subcultures that pay specific attention to masculine hierarchies - for example, in prison subcultures. ${ }^{34}$ Second, drinking provides

\footnotetext{
${ }^{29}$ Note that violence is also characterized by the overwhelming involvement of men: 56 percent of all homicides are men's attacks on other men. See Krista Eckhardt and William Alex Pridemore, "Differences in Female and Male Involvement in Lethal Violence in Russia," Journal of Criminal Justice 37 (2009): 62.

${ }^{30}$ Douglas, “A Distinctive Anthropological Perspective," 7.

${ }^{31}$ Brian P. Hinote and Gretchen R. Webber, "Drinking Toward Manhood: Masculinity and Alcohol in the Former USSR," Men and Masculinities 15:3 (2012): 298. Even when women are also involved in collective heavy drinking, they are perceived as invisible participants of the ritual, whereas the main exchange occurs between men and is focused on their behavior vis-à-vis one another.

${ }^{32}$ Hinote and Webber, "Drinking Toward Manhood," 300.

${ }^{33}$ Douglas, “A Distinctive Anthropological Perspective," 8.

${ }^{34}$ Note, for example, the following testimony from a former prison inmate on the structure of prison community: "When getting to know people and in further communication, it is important to consider the division of the prison society (in a broad sense) into castes. First, there are people and non-people. The people consist of men, vagabonds and thieves. All the rest are not considered people-these are the connected, offended, freaks, sluts, and so on. The main - the most populous - castes are three: the men (muzhiki), the connected (viazannye) and the offended (obizhennye). A man is a normal inmate who does not work with the prison administration and does not do passive homosexuality (there are more criteria, certainly, but these are the major ones). The connected (the reds, goats, or nanny-goats) is an inmate who works for the administration and janitors. <...> As for the offended (they are also the roosters [petukhi]), I guess, everyone knows who they are, although many
}

access to masculinity (initiation ritual), as young boys or masculine women may be included in the company of adult men by proving they can drink. ${ }^{35}$ So masculinity does not have a biological foundation in this context, though it relies heavily on bodily expressions of gender. Third, the ritual of drinking alcohol is a set of exchanges of respect between men: it is a process of sending and receiving signals that should be interpreted by the participants as a show of respect, that is, the recognition of one's masculine status. Every glass poured is an invitation to engage in this exchange. ${ }^{36}$ This idea requires some further explanation. 
One of the most important phrases of the drinking ritual in Russia is the question, "Do you respect me?", which scholars generally interpret as a type of manipulative tactic meant to pressure the participants to continue drinking ${ }^{37}$ Yet while it may be partly manipulation, it is also an expression of the major exchange value in the ritual: the degree of masculinity. The people who are engaged in drinking together are assumed to start this ritual from a position of equal degree of masculinity. The participants of the drinking ritual are all equals who mutually respect each other by recognizing their equal masculinity. Thus, when one intends to leave the table, he is asked about his respect for others not because other participants actually seek his respect or want him to stay, but because he is challenged to recognize his failure to drink as much as the others do, and by doing so to continue the confirmation of his masculinity. In other words, the question "Do you respect me?" is also the question "Are you man enough?", or "Do you recognize that I am more of a man than you?" If you do not drink further, you are no longer equal, and you are now a lesser man than those who stayed. This is why for many men this question is a signal to stay at any cost, because otherwise they lose what they came for: their masculine status connected to the respect of other people (if they leave, they will be ashamed) and personal dignity. Respect is, therefore, not a rhetorical question, but a value that is being exchanged in the ritual of collective drinking.

As this practice occurs in an intimate space, the setting for drinking alcohol is usually someone's private apartment. ${ }^{38}$ Heavy drinking in public spaces such as city squares or parks may also occur, but it may convey different rationales: for example, the assertion of masculinity through the public manifestation of one's ability to drink a lot. The element of

may be surprised to learn how easily one can become the offended. In Moscow, usually there are no problems with this, because they do not put the connected and the offended in the same barrack with the people, but in other regions (for example, in Chelyabinsk or Krasnoyarsk) the connected and the offended may be placed under the same roof with the men. This is why before shaking hands with someone or drinking tea with someone there, you have to ask: 'Is everything normal in your life?' (Po zhizni vse rovno?)" (last accessed at http://w-os.ru/article/3787 on December 6, 2018).

${ }^{35}$ Hinote and Webber, "Drinking Toward Manhood,” 301.

${ }^{36}$ Koester, "Drink, Drank, Drunk," 42.

${ }^{37}$ Dudeck, "Do You Respect Me?," 99; Koester, "Drink, Drank, Drunk," 42. The logic of this manipulation is that if one of the participants intends to step out from the drinking circle, he is then asked whether or not he respects the rest of the participants. If he does, then he will continue drinking. If he insists on leaving the table, then he shows disrespect.

${ }^{38}$ Notably, violent crimes in many cases occur between people who know each other and in private settings: "Inside homes is the most common place for a murder to occur in the [Russian Federation's] Udmurt Republic according to these narratives. Nearly 60 percent of the murders occurred in someone's home, and in more than 40 percent of the cases, the event took place in the victim's home" (Pridemore, "Exploratory Analysis of Homicide Victims," 14).

intimacy and exchange of mutual respect is lost in this case, although the reinforcement of masculinity is still at the heart of the practice. The material we analyze contains few stories of public drinking; the overwhelming majority of crimes occurred in private. Therefore, it is also important to note another aspect of this interaction ritual: this intimate space is a space of sharing. ${ }^{39} \mathrm{We}$ have already mentioned that, while drinking alcohol, people in Russia not only exchange signs of respect but also share their most secret thoughts and concerns. This practice is embedded in the very social fabric of drinking: privacy, the ceremony of mutual respect, and the practice of sharing alcoholic beverages and appetizers facilitate and encourage intimate conversations. David Koester cites this feature as one of the major traits of the drinking ritual in Russia:

They drank together and shared conversation and personal information in confidence. Such "secrets"- statements that are intended to circulate only within a defined group of people - give drinking circles the character of secret societies. ... Drinking is thought to and indeed does encourage free speaking within the drinking group. There is a trust that things said within the drinking circle will not be shared with outside others if to do so would have negative (embarrassing) consequences for the members of the circle. ${ }^{40}$ 
This practice of intimate confessional talk is called a "conversation of souls" (razgovor po dusham), which literally means simply a frank conversation. ${ }^{41}$ Alcohol consumption encourages a conversation so open-hearted that the participants' "souls" can talk. As we show further, this is the point where major tension in the drinking ritual may emerge: as a very private practice of crafting masculinity, drinking rituals also offer a space for personal confessions that may in fact be perceived as threats to masculinity. In particular, homosexual coming out in a group that has gathered to engage in the mutual confirmation of the participants' masculinity appears as a breakdown of the ceremonial procedure and, consequently, may result in violence, including fatal injury. Importantly, if the ritual of drinking alcohol were organized differently (for example, if it could accommodate sexual and gender diversity, or if it did not encourage a "conversation of souls"), violence would probably not take place in these social interactions.

\section{VIOLENCE AND CRIMINAL PROCEDURE}

Our further analysis is based on the review of court rulings across Russia in 2011-16 and builds on some of our previous work, in which we studied coming out episodes that occurred during the consumption of alcohol as part of larger research project on violence against queer people in Russia. ${ }^{42}$ In our research, we accessed databases of court records maintained

\footnotetext{
${ }^{39}$ Dudeck, "Do You Respect Me?," 91, 98.

${ }^{40}$ Koester, "Drink, Drank, Drunk," $42-43$ (in-text references in quote omitted).

${ }^{41}$ See Evgeny M. Shtorn's "Ubiistva negeteroseksualov na pochve nenavisti (analiz materialov sudebnykh reshenii)," Sotsiologiia vlasti 30:1 (2018): 60-78. See also Sokolov, "P'ianka," 50.

${ }^{42}$ Kondakov, "Influence of the "Gay-Propaganda' Law"; Shtorn, "Ubiistva negeteroseksualov"; Evgeny Shtorn, "Esse o sublichnosti: Dvukratnaia popytka pogovorit' o nasilii,” Zhurnal sotsiologii i sotsial'noi antropologii 20:5 (2017): 207-21.
}

by the Ministry of Justice of the Russian Federation and by independent lawyers, and then created our own database, "Russian Court Decisions on LGBTIQ Cases." ${ }^{43}$ Both databases contain anonymized full texts of court decisions and have search engines. By using key words, we identified and downloaded all cases related to queer sexualities, which numbered more than three thousand files. We excluded documents related to, for example, the implementation of the law on the "propaganda of non-traditional sexual relations," intimate partner violence in same-sex couples, cases of offended police officers referred to as "homosexuals" on the streets, and so on, focusing solely on those cases involving felony violence against queer people. To identify these cases, we looked for criminal rulings where the victim's sexuality was revealed and the perpetrators acted out of "negative feelings" toward them or specifically targeted queer people. Overall, 267 such documents were found in these databases for the years 2011-16, and they dealt with crimes against 297 victims.

Initially, this project aimed to establish the number of victims of violence against queer people in Russia before and after the "propaganda" law. As mentioned at the outset of this article, it was shown that after 2013, when the bill against the "propaganda of homosexuality" was first introduced, the number of victims of violent incidents grew and, in 2015, had doubled in comparison to $2012 .{ }^{44}$ Clearly, these cases do not encompass all of the violent acts perpetrated against queer people in Russia, but only those that reached the courts. In order to reach the courts, incidents have to be reported to the police and then properly investigated. Moreover, the prosecution had to agree with the investigation and file the case with the court, which in turn had to hear the case and issue the final ruling. Certainly, each of these stages could become an obstacle on the way to a case coming to our attention, starting from the very first step, the report to the police, especially in the context of the mistrust between queer people and law enforcement officials in Russia.

What is probably more important for this particular study is that the documents had to contain a clear indication of the victim's sexuality to be considered. Since this analysis of sexuality and alcohol rituals departs from a 
quantitative approach and engages with qualitative methods, it is important to know that the language of criminal court files may not always be explicit on sexual matters, even if sexuality was crucial to a case. Reading these documents convinced us that the sexual vocabulary of judges is extremely limited in Russia. Most commonly, they refer to queer sexuality with the very broad category of "non-traditional sexual orientation," which seems inclusive of almost anything outside of monogamous heterosexuality. Furthermore, some case files contained large paragraphs where sexual terms were censored (the words were redacted with the use of signs such as "<... $>$ "). Only because of the negligence of the people who prepared the texts for online publication could we discern what the texts were talking about; for example, when those editing a document accidentally failed to redact the same term they had redacted in a

\footnotetext{
${ }^{43}$ The official database is open to the public and can be accessed at https://bsr.sudrf.ru/bigs/portal.html. The independent database ceased functioning in early 2018. Previously it could be accessed at https:// rospravosudie.com/. The major identifiers of any court ruling in Russia are the case number, the place where the decision was made, and the region (if any) where the place is located. With this information any interested reader may access the official public database and find the relevant case.

${ }^{44}$ Kondakov, "Influence of the 'Gay-Propaganda' Law," 13-14.
}

preceding paragraph. Finally, there might be criminal cases across Russia in which the homosexuality of the victim was part of the story, but still never appeared in the text due to the judges' reluctance to even enunciate sexual language. These reflections led to the idea of a deeper qualitative study of these texts.

All of the cases that we are dealing with fall under the Criminal Code of the Russian Federation. Therefore, these cases are violent offences ranging from mild (and already decriminalized) battery (Art. 116) to intentional murder (Art. 105). The Criminal Code articles that feature most prominently in the database we compiled involve various physical injuries $(111,112,115,116)$ and types of murder (sections of Art. 105). Criminal procedure is regulated through separate legislation, the Criminal Procedural Code, a relatively sophisticated set of rules on what counts as evidence or what circumstances should be considered when making a final decision. The procedural code is, therefore, a sort of framework for the appearance of our object of analysis - the judge's ruling, as a criminal court document. We take this into account in our methodological considerations.

Because criminal rulings are legal procedural texts, they mostly contain language and information relevant to the final decision. If a defendant is convicted (which was the case in all the documents we reviewed), the whole text of the court decision directs readers to that particular conclusion of guilt. Hence, little information that does not correspond to this final aim, or that seems irrelevant for such a narrative, remains in the text. But what does remain is still very informative. Russian court verdicts are relatively long texts, averaging 20-25 standard pages. In them, judges summarize the events of the court hearing: they state who is present; who is being convicted and for what deeds; what happened at the scene of the crime as recalled by various participants (defendants, victims, eye witnesses); what arguments support or contest different versions of the given event (material evidence, forensics, and testimonies); what the personal characteristic of the defendants are; and the reasoning behind the judge's final ruling. All these elements are presented in accordance with the Criminal Procedural Code. Thus, this structure is both formulaic and strict.

At the same time, the texts of the court decisions do not belong to just one author, the judge. The composite nature of these texts means that they are created over a long time by a variety of authors. ${ }^{45}$ The investigating officers record testimonies about the events and collect material evidence at the earlier stages of a case, as well as produce their own relevant official documentation. They also translate people's everyday accounts into legal language together with the prosecutors, who then present the case in the courtroom. However, participants in the event in question also contribute their own vocabularies, ideas, or narrative structures. Forensic experts form another group. Then there are defense attorneys and court clerks, especially the secretary at a given hearing who most probably compiles the final document for revision by the judge. All of these voices appear in the case files we studied, revealing changes in style, vocabulary, narrative, and even spelling in almost every single ruling. Therefore, we deal with a mosaic of various accounts that were pulled together to serve an ultimate goal within 
the criminal procedure. An illustrative example may prove this point when two different languages that appear in the same short phrase are compared

${ }^{45}$ Alexander Kondakov, "The Feminist Citizen-Subject: It's not About Choice, It's About Changing It All," Feminist Legal Studies 25:1 (2017): 47-69.

vocabulary of a defendant's testimony):

As [the defendant] knew, F. abused alcoholic beverages consumption and had inclinations towards non-traditional sexual orientation, namely he was a homosexual. Because of this, F. had few friends, or, in fact, he only had drinking pals (sobutyl'niki). [The defendant] personally had no friendship with $\mathrm{F}$., rather he had unpleasant feelings toward him because of his lifestyle (zhiznennaia pozitsiia). $<\ldots>$ on Friday at about 11:00 A.M., [the defendant] cannot say more precisely, he decided to visit F., so that the latter would finally choose who he was in life: namely, whether he was a homosexual or a normal guy (normal'nyi muzhik), i.e. [the defendant] went to him to raise this issue (pred"iavit' pretenziiu). On that day, in the morning, [the defendant] drank a small bottle (chekushka) of vodka. He came to F.'s apartment, knocked on the door, F. opened it, he was home alone. Right away (s poroga) without going inside, he started to speak out (vyskazyvat') about F.'s lifestyle (zhiznennaia pozitsiia), in response F. called him names. ${ }^{46}$

Although presented as a consistent narrative of only one person (the judge), this text contains at least two different vocabularies: one offered by the defendant in his testimony and unedited; the other one edited by the prosecution or investigating officers and revised by a judge to translate important circumstances from everyday language into legal language. The defendant's own words indicate his social status and life experience, as he uses many simple slang constructions to express himself. When the words of the defendant mean something in legal terms, legal language has been inserted in their stead (underlined in the text above). For example, apart from the legal context, no one uses "unpleasant feelings" to refer to negative emotions towards someone. People would rather say they dislike or at least judge someone for their lifestyle, but not that they have "unpleasant feelings" toward them. Yet, in law, "unpleasant feelings" is a category that counts as a motive for violent criminal offenses. This category is very important because in fact it is used as a substitute for "hate" in many cases: if "hate" is used, then the criminal procedure becomes more complex and time-consuming in terms of investigation and prosecution, because proving a hate crime motive is regulated by a separate hate crime law; whereas if "unpleasant feelings" are offered as a motive, there is no complicated procedure to follow and a defendant's vague testimony of having negative feelings toward his victim is enough. This is why it was important to translate whatever negative characteristic the defendant offered for the victim's "lifestyle" to the legal notion of "unpleasant feelings," while the rest of his narrative could remain more or less as he put it. Such a strategy has been used in cases involving queer victims, and in other cases where investigators feel it is appropriate and where they do not want to spend time proving other motives. Bearing in mind these suggestions, read the following passage from another case:

He did not commit crimes in the way they were described in the indictment. He thought that with his actions he fought against persons of non-traditional sexual

${ }^{46}$ Case \#1-16/3012, Semenov, Nizhnii Novgorod. Originally, a chekushka referred to a quarter-liter bottle of vodka, but currently it may refer to any bottle smaller than a standard 0.7-liter bottle of vodka. 
orientation and pedophiles. Because of his youthful overreaction-which he now believes is just foolish - he thought that he was making this world a better and brighter place. This was in relation to four victims: [victim-1], [victim-2], [victim-3], and [victim-4]. He kept all the video files and believed that they would help him keep the <redacted $>$ from their immoral acts. At the very beginning, it was just a game, but then he came to believe he was making the world a cleaner place. ${ }^{47}$

This text represents a more complex combination of the perpetrator's narrative with the legal professionals' intervention. This defendant is a very young man who had barely turned eighteen, and because of this he received compassionate treatment from the investigators and the court (as our reading of the case suggests). His narrative was most probably controlled by the investigators to ensure a mild sentence compared to that handed down to his much older accomplices. This is why it looks like a more or less organic blend of legal and colloquial language, yet it manifests vocabularies of various kinds. For example, this very young man would hardly use the words translated above as "youthful overreaction" and that sound like "iunosheskii maksimalizm" in Russian. This notion is too Soviet to be used by a person without any Soviet experience. Most probably, the phrase got into this narrative from the investigators' vocabulary, although it has nothing to do with legal qualification of the case (but could play an important role in the application of Soviet law).

Considering these details, it would be incorrect to say that these court documents represent a one-sided picture. In fact, the court rulings reflect different voices, perspectives and accounts of an event under judicial review. It is true that they are pulled together by the logic of criminal procedure. Nonetheless, they are compilations of a wide range of individual stories with their own logics and vocabularies. This complexity makes the documents a very rich source of information about relevant and circumstantial evidence regarding the issue in question-the social norms that can drive the interaction ritual of alcohol consumption toward brutal murder.

\section{COMING OUT UNDER THE INFLUENCE OF ALCOHOL}

Of all the identified cases of violence against queer people in Russia (267 documents), 165 court files involve the consumption of alcohol and 143 describe private apartments as the crime scene. We mostly focus on the 37 cases that revolve around the victim's coming out. What we analyze further is a specific interaction ritual reconstructed from the court testimonies of the participants. In this analysis we seek to find the features of the drinking ritual discussed above. This analysis helps to view sexuality and masculinity in the context of the cultural norms of collective drinking in Russia. The sample includes cases from all over Russia, ensuring that it is very culturally diverse in terms of the ethnicities and religious affiliations of those involved. However, the sample is also specific in one respect. Judging by the descriptions of the social environment (smaller towns and apartments, poverty), the stated professions of the participants (unemployed, occasional jobs, manual labor), possessions (inexpensive cellphones), and, ultimately, drinking habits (hard liquor), the

${ }^{47}$ Case \#1-285/2015, Chita, Zabaikalskii Krai.

majority of participants — including victims, perpetrators, and witnesses — belong to the lower classes of society. Although explicit information is scarce, we believe that we are dealing with the drinking habits of working-class people across Russia. ${ }^{48}$

One important note before presenting the analysis concerns the notion of "coming out." Just like in many other places, in Russia, sexuality is not necessarily formed around a stable sexual identity. ${ }^{49}$ Rather, sexuality is an elusive field of practices and self-reflections that includes a range of ways people may identify their sexual selves from such usual sexual categories as "gay" or "lesbian" to vague allusions and references to sexual vocabularies that place a person on the queer spectrum, but do not point directly to a category of identity. ${ }^{50}$ In other words, some Russian queers acknowledge their sexual identities and come out as, say, "gay men," but others use different forms of queer self-presentation by refusing to pass as heterosexual, by giving ambiguous hints about their queerness, by bodily expressions of gayness without a vocal articulation of gay identity, and by many other means. ${ }^{51}$ This situation is conditioned by the long-standing repression of sexual language in the Soviet era, and by 
the association of gay and lesbian identities with a type of politics (LGBTQ activism) that was to be avoided. ${ }^{52}$ Given this, we regard "coming out" as a varied practice of queer self-presentation, even if it is not the usual recognition of the speakers' sexual identity verbalized in rigid categorical language. After all, as many of the researchers referenced here have shown, queer sexuality in Russia is a fluid and ambiguous practice and, therefore, reading it through "Western" identity language may be misleading. Thus, "coming out" here is a metaphor that refers to many forms of sharing intimate information about one's sexual self.

Our discussion of drinking rituals includes one of the intimate elements of this process, namely the "conversation of souls." This peculiar phenomenon refers to an honest conversation between people engaged in drinking. Such a conversation is frank because

\footnotetext{
${ }^{48}$ Court rulings are published in anonymized form, and because of this many personal details (such as previously held jobs, education, and age) are not always available (however, in some cases, these details are left in the court decisions anyway). Nonetheless, the circumstantial evidence in most of the cases references economically deprived environments. For example, since many cases involve property theft that occurs after violence, the courts describe prices of the possessions taken from the victims. Most commonly, these are cellphones in the lowpriced range of models. A more detailed analysis of this evidence would require a separate study. Note also the link between the fragility of heterosexual masculinity and economic deprivation.
}

\begin{abstract}
${ }^{49}$ Much has been written on identifying-traits and characteristics of the peculiar queer subjectivity in Soviet and post-Soviet Russia. The argument advanced in the existing literature is that the homosexual subject has never fully emerged in Russia because, instead of manifesting as a sexual identity, it has retained its elusiveness and fluidity. See Essig, Queer in Russia, esp. "Part II: Self"; Stephen Amico, Roll Over, Tchaikovsky! Russian Popular Music and Post-Soviet Homosexuality (Urbana, 2014); and Francesca Stella, Lesbian Lives in Soviet and PostSoviet Russia (Basingstoke, 2015). For a methodological discussion of reading "gay identities" in Russia that identifies a simultaneous mixture of typically "Western" identitarian language coexisting with more elusive vocabularies that deny categorical identification see Brian James Baer, "The Other Russia: Re- Presenting the Gay Experience," Kritika: Explorations in Russian and Eurasian History 1:1 (2000): 183-94.
\end{abstract}

${ }^{50}$ Alexander Kondakov, "Crip Kinship: A Political Strategy of People Who Were Deemed Contagious by the Shirtless Putin," Feminist Formations 30:1 (2018): 79-80.

${ }^{51}$ Sergei Mozzhegorov, "Strategii gomoseksual'nogo raskrytiia v lichnostnykh narrativakh rossiiskikh geev i lesbiianok," Zhurnal sotsiologii i sotsial'noi antropologii 16:3 (2013): 172-87. For the vocabulary of coming out that exists at the intersection of disability and queer sexuality see Kondakov, “Crip Kinship,” 80.

${ }^{52}$ Alexander Kondakov, "Rethinking the Sexual Citizenship from Queer and Post-Soviet Perspectives: Queer Urban Spaces and the Right to the Socialist City," Sexualities 22:3 (2019): 411.

[50]

one cannot betray the social bond and respect that has been established by engaging in the intimate practice of sharing an alcoholic drink in someone's home. This is why, when confronted, people openly speak up in these situations: "He then saw that [Name2] hugged [Name37] and so he asked [Name2] about his sexual orientation, and [Name2] confessed that he was a homosexual." ${ }^{53}$ The conversation of souls also suggests that one may initiate talk about one's sexuality without being prompted, just like in the case presented at the outset of this article, when three men were celebrating International Women's Day. In this case, alcohol facilitated such a conversation. This is also evident in another case, with an indication of the degree of intoxication at the moment of coming out: "These people started to drink alcoholic beverages, and while drinking and being very drunk [the victim] informed him that he was a homosexual." 54

When people drink and have a "conversation of souls," they speak with unusual frankness. Sometimes they may confront their drinking mates and bring up sexual matters that they probably would not discuss on other occasions. In these cases, alcohol serves as a social lubricant to facilitate the "conversation of souls," but at the same time the confessing party may encounter a lack of understanding:

They started to drink the second bottle of cognac and remembered their old friends. When they remembered [Name7], [the defendant] mentioned that [Name7] was a homosexual. [The victim] was very surprised and did not believe in this news, he said there was nothing wrong in being a homosexual because this was everyone's right and nobody could judge people for this. ... Five 
minutes later, [the victim] started to talk again about homosexuality being normal and that nobody should judge people for this. Because of this, ([the defendant] and [the victim]) started to argue once again. ${ }^{55}$

Their argument escalated into a fight with fatal consequences for the victim. These varied forms of revelations or confessions hint at desires beyond heterosexuality. These confessions appear in different forms. One can, for example, neither confirm nor deny information about one's sexuality, and this would also be a form of honesty and respect to the participants of the drinking group: "he asked [the victim] whether or not he was a homosexual and [the victim] smiled without saying anything." 56 The important thing here is that such a conversation over drinks facilitates frankness, honesty, confessions, and revelation of information that has been previously kept secret, no matter what form the coming out takes.

Yet this honesty was not appreciated in the cases we analyze here. Of course, cases in which someone's coming out during a drunk "conversation of souls" was met with friendliness and understanding are not part of our criminal incidents sample, because friendliness is not a criminal offense. This means that we are looking at specific situations in which some participants of the collective drinking ritual perceive the coming out as breaking the rules of the interaction. A conflict arises whenever different participants'

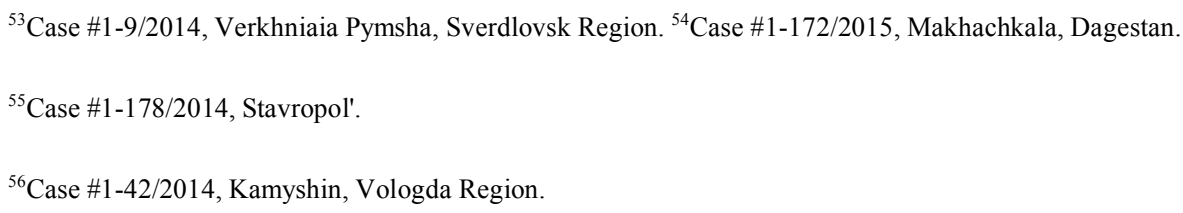

interpretations of the norms of this ritual clash. For example, in one of the cases, a participant of the drinking gathering felt compassion for another participant who had come out as bisexual. He believed that this was not such a big deal, and that they might still restore their usual social relations if the bisexual person denied his sexuality: "he asked [the victim] to say that he was not like this so that everyone would stop beating him, but [the victim] only replied he did not care if it were a boy or a girl, so he did not even understand his situation., ${ }^{57}$ Meanwhile, the other participants of the gathering continued drinking alcohol and beating up the bisexual person, whom they took outside of the common room to the apartment's hallway. They spatially separated the victim and occasionally went out to kick his face with their boots.

Because the drinking ritual's rules are not set in stone, differing interpretations of them create room for such gatherings to proceed in a variety of ways. But those differences also make conflict possible, which in turn destroys the felt commonality of the practice. We argue that the latter happens in cases when perpetrators are not prepared to recognize the equality of a queer participant in the drinking ritual due to the alleged lack of masculinity in queer subjectivity. In these cases, they perceive the situation as a personal affront because, if they continue drinking together, they too become "degraded":

In the period of time from 11:00 P.M. to 11:15 A.M. on <date>, [the defendant] drank alcoholic beverages together with his recent acquaintance [the victim] in his apartment. ... During the consumption of alcohol, [the victim] informed [the defendant] about his attraction to him. [The defendant] perceived this idea as an affront to his honor and dignity, and because of this ... [the defendant] acquired the criminal intent to murder [the victim] based on his personal unpleasant feelings. ${ }^{58}$

The participation of a homosexual man in the common masculine practice of drinking alcohol is perceived as threatening by other participants, because since the participants are equals, they could all be considered queers. This norm points to the fragility of heterosexual masculinity, which must be defended by getting rid of the queer element in the drinking ritual. In order to reestablish the equality of drinkers, the perpetrators believe that they must restore the presumed heterosexuality of the participants: 
At 11:00 P.M., [witness-1] woke up and found a company in his kitchen: there were [the defendant] and [the victim] among them. He learned from those present that [the victim] revealed that he was an adherent of a non-traditional orientation. [The witness-1] asked [the defendant] to show [the victim] the way out from his apartment. ... [The defendant] was found in a state of heavy alcoholic intoxication, but he still confirmed that he beat [the victim] up, though [the defendant] did not know that [the victim] died. Sometime later, already at the precinct, [the defendant] personally and without knowing the charges against him confessed that he started to make [the victim] leave the apartment because of [the victim's] sexual orientation. ${ }^{59}$

${ }^{57}$ Case \#1-9/2016, Neriungri, Sakha. ${ }^{58}$ Case \#1-376/2016, Izhevsk, Udmurtia. ${ }^{59}$ Case \#1-338/2015, Briansk.

As we see in this and other examples, homosexuality serves as the basis for exclusion from the company of men, including spatial exclusion. The reviewed cases suggest that queer people are also murdered to ensure this exclusion. The case that took place on International Women's Day makes it clear that this happens because queer men are understood to be not men enough, and thus feminized. Therefore, they have no place in a masculine company engaged in asserting their masculinity and, consequently, are violently punished:

[the victim] told him that he did not like the female sex in general and that he had negative feelings toward women. [The defendant] was apparently hurt by this news and continued to interrogate [the victim] why he had this attitude toward women. [The victim] explained that he was a person of nontraditional sexual orientation. After these words, [the defendant] became furious, started to curse and call him names. [The defendant] asked why [the victim] did not inform him previously about his non-traditional sexual orientation. They both rose from the table, and [the defendant] started to beat [the victim]. ${ }^{60}$

This story clearly shows how a very ritualized ceremony evolves into a violent confrontation: three men sit at the table face to face, drink hard liquor, and talk candidly about personal issues; then, one of them reveals his sexual orientation as a courtesy to the host, following the rules of honesty appropriate to the "conversation of souls" and answering direct follow-up questions. Instead of receiving the revelation as a sign of respect, the host interrupts the ceremony because he cannot recognize queer masculinity as appropriate for equal treatment symbolized by sitting at the same table and sharing a drink. The impossibility of continuing the ritual is evident when the defendant asks why the victim did not reveal his sexuality earlier: if he had, they would not have shared drinks at all, and so the defendant would not have lost his dignity through sitting at the same table with a gay man. This norm of exclusion of queer people from sharing drinks and food is reminiscent of the rules in Russian prisons where male inmates believe in a very strict sexual hierarchy and do not allow the so-called opushchennye (the "caste" of the degraded) to sit at the common dinner table or share anything with other inmates. ${ }^{61}$ In the cases reviewed, there are episodes that involve former prison inmates who introduce this norm to the rest of the participants in the drinking ritual:

An unknown young man approached them, said hello and started to say that they were sitting together with an opushchennyi pointing at [the victim]. [The defendant] immediately asked [the victim] whether what was said about him was true, and [the victim] hung his head and said nothing in response. After that, he asked [the victim] to stand up and walk with him behind the garage located several meters away from the bench where they sat. When they were behind the garage, he asked again whether or not it was true, but [the victim] kept silent. Then he asked why [the victim] did not warn him that he was opushchennyi despite their previous close relationship before [the victim] abused drugs. Then he hit [the victim's] face with his right-hand fist. ${ }^{62}$

${ }^{60}$ Case \#1-3/2014, Shimanovsk, Amur Region.

${ }^{61}$ Opushchennye are prison inmates who are forced to perform sexual services for other prison inmates. ${ }^{62}$ Case \#1-37/2013, Nizhnii Novgorod. 
In this episode, the victim "comes out" by remaining silent in response to a direct question about his sexuality. According to prison norms, touching a queer inmate or eating together with him means becoming queer, too. This is why sharing common spaces, drinks, or even feelings (such as respect) between presumed heterosexual men and queer people is strictly prohibited. This rule is also in evidence beyond prison walls, and it structures the drinking rituals: "while drinking alcohol, [the victim] explained that he was a person of non-traditional sexual orientation, and because of this [the defendant] was offended according to the norms of prison inmates (poniatiia), because living together with such a person was offensive." ${ }^{63}$ This idea appears in a number of court decisions. We do not want to overemphasize the influence of prison culture, because many cases do not refer to it in any way, but it is still important to note as one type of social context.

The cases we have reviewed show that drinking rituals happen in domestic spaces, spaces that facilitate the creation of intimacy between men who may engage in a conversation of souls. These conditions of privacy, shared drinks, and intimate settings facilitate honesty and sharing mutual recognition and respect, including in the form of confidences. Thus, queer participants of these interaction rituals may feel it appropriate to reveal their sexuality to their drinking mates, who are also their "soul mates" in that moment. Yet the cases we have studied show that this honesty is not appreciated by certain participants of the collective drinking ritual. Instead of showing mutual recognition and respect for receiving the confidence, they feel offended and threatened. As a result, they get rid of the element they believe has polluted the shared social space created by the drinking ritual. The intimacy that is created for the men does not include sexual engagement between them, at least not in any recognizable form.

\section{CONCLUSION}

Collective drinking among men is a ritual of confirmation of heterosexual masculinity through the practice of communal consumption of alcohol. In the cases reviewed, drinking occurs in intimate male company with three or more people demonstrating mutual respect for each other with every new shot of vodka. The process of drinking creates valuable social space in which men may produce and affirm their masculinity; yet this masculinity, in the end, seems very fragile. They start with the assumption of being equal, but then assert a hierarchy based on the amount of alcohol consumed. And the intimate space they create becomes an arena of masculinity in which a very fragile object is not only being crafted but also is always potentially threatened. In particular, masculinity is threatened by an encounter with unexpected sexual diversity. Since these men are not ready to accept queer sexuality as equal, they react by excluding it altogether from their rituals. The exclusion comes in different forms: from physical segregation to murder.

These cases represent extreme instances of violence. Not every coming out during drinking results in violence. Hypothetically, nevertheless, we may suggest that many instances of coming out result in some form of exclusion. Murder may be a very rare form

${ }^{63}$ Case \#2-13/2015, Ivanovo.

of excluding queerness, but there are other means to which people may resort and which are not regarded as criminal offenses. ${ }^{64}$ Yet those other forms also work as social mechanisms of oppression and violence. The limitation of this study is that we can see only the forms of exclusion revealed by the criminal procedure. It is worth pursuing other paths and methodologies in the study of rituals that inform social interactions.

Russian men were reminded of the fragility of their masculinity when discussion of the "gay propaganda" law got under way in 2011, when regional parliamentarians across Russia initiated anti-queer legislation to protect heterosexual fragility. In 2013 the "propaganda of non-traditional sexual relationships" was banned on the federal level. The legislation highlighted the threatening nature of homosexuality, as did the state-owned media outlets covering the legal innovation. ${ }^{65}$ It was suggested that heterosexuality is not stable, that it could be easily lost if a person was exposed to information about homosexuality or found themselves in the proximity of a queer person. Although even without the law and the discussion surrounding it, many men feel that their heterosexual masculinity is fragile, the law pointed it out and set in motion events that led to violence: as a protectionist law, it 
confirmed the need to defend heterosexuality. Some men eagerly responded to this call by acting violently against men whom they saw as contagious. These murderers and lawmakers share a feeling of insecurity about their gender and sexuality, a feeling that can only be relieved, we argue, by recognizing the multiple ways in which gender and sexuality are expressed in society, making it a more diverse place.

${ }^{64}$ Consider, for example, the forms of online violence discussed in Tetyana Lokot, "Affective Resistance against Online Misogyny and Homophobia on the RuNet," in Gender Hate Online, ed. Debbie Ging and Eugenia Siapera (Cham, 2019), $213-32$.

${ }^{65}$ Pronkina, "Osobennosti LGBT-diskursa."

$[55]$ 